\title{
A Network Pharmacology Exploring the Mechanism of a Chinese Medicine Pair for the Treatment of Gout
}

\section{Wenjia Zhao ( $\nabla$ wenjiazhao@aliyun.com )}

Shanxi hospital of traditional Chinese medicine https://orcid.org/0000-0001-9945-3517

\section{Wei Liu}

First Teaching Hospital of Tianjin University of Traditional Chinese Medicine

\section{Yuanhao Wu}

First Teaching Hospital of Tianjin University of Traditional Chinese Medicine

\section{Original Article}

Keywords: targets prediction, pathways analysis, action mechanism, gout

Posted Date: February 9th, 2021

DOI: https://doi.org/10.21203/rs.3.rs-174064/v1

License: (c) (i) This work is licensed under a Creative Commons Attribution 4.0 International License. Read

Full License 


\section{Abstract}

Background:

Gout is a crystalline-related arthropathy aroused by monosodium urate aggradation, which directly have a bearing on the disturbance of purine excretory and/or hyperuricemia, and seriously affects human health. In China, Dioscoreae Hypoglaucae Rhizoma (DH) and Smilacis Glabrae Rhixoma (SG) are widely used as medicinal pairs to prevent and treat gout. However, there is still a lack of research on the mechanism of DS (DH and SG). The aim of this study is to identify the absorbable components, potential targets and related therapeutic pathways of DS by means of network pharmacology.

Material/Methods:

We searched the effective chemical components of DS from TCMSP database, and explored the target of DS from GeneCards, a Bioinformatics Analysis Tool for Molecular mechANism of Traditional Chinese Medicine (BATMAN-TCM) and STITCH database. Databases such as Online Mendelian Inheritance in Man (OMIM), Therapeutic Target Database (TTD) and Pharmacogenomics Knowledgebase (PharmGkb) were used to query treatment targets for gout. Cytoscape software was applied to build the network map, KEGG database was applied to analyze the pathway of action, and finally a multi-component-multi-target-multichannel DS treatment gout network was formed.

Results:

We found 16 active components, 24 KEGG metabolic pathways and 47 common targets of DS. The herb couple DS shares 9 targets with gout, including NOD like receptor protein 3 (NLRP3), Steryl-sulfatase (STS), Ephrin type-B receptor 2 (EPHB2), 5'-AMP-activated protein kinase catalytic subunit alpha-1 (PRKAA1), ROS Proto-Oncogene 1, Receptor Tyrosine Kinase (ROS1), Solute carrier family 22 member 12 (SLC22A12), Phospholipid-transporting ATPase IB (ATP8A2), Interferon regulatory factor 6 (IRF6) and P2X purinoceptor 7 (P2RX7), which may be the key point of DS in the treatment of gout.

Conclusions:

In this study, we tried to explain the mechanism of DS in the prevention and treatment of gout by using the network pharmacological method and provided an alternative way to study the effect of this Chinese medicine pair.

\section{Introduction}

Gout is a crystalline-concerned arthropathy aroused by the sedimentation of monosodium urate (MSU), which directly have a bearing on the disturbance of purine excretory and/or hyperuricemia (Smith et al. 2014). Globally, the prevalence of gout in developed countries is higher than that in developing countries. Gout is common in North America and Western Europe, with prevalence ranging from 1-4\% (Janssen et al. 2017). The onset of the disease is gradually younger and younger (Pillinger et al. 2017). 
Colchicine, non-steroidal anti-inflammatory drugs, glucocorticoids, uric acid and allopurinol, are in general use for the treatment of gout (Doghramji et al. 2016). However, a lot of current medicine treating gout have various side effects, containing anaphylactic reaction, transaminase increase and gastrointestinal reaction (Engel et al. 2017). Consequently, traditional Chinese medicine (TCM) have recently been much account of owing to good effect and less adverse reaction.

Drug pair is a commonly-used combination of two Chinese medicine frequently appeared in TCM clinic, and it is the basic composition of prescription of TCM. Dioscoreae Hypoglaucae Rhizoma (DH) and Smilacis Glabrae Rhixoma (SG) are the most general used pairs of TCM to cure gout (Shen et al. 2017). However, the molecular mechanism(s) of DS (DH and SG) in the remedy of gout still needs to be researched. The study of network pharmacology can reveal the mystery of drug action on human body by systematically observing the intervention and influence of drug on biological network (Johansson et al. 2017; Lin et al. 2017). TCM have the advantages of multi-component and multi-target, which conforms to the research method of network pharmacology. The strategy of biological network analysis adopted in this study may be helpful to discover the molecular mechanism of gout treated by this drug pair.

In this study, we collected the effective therapeutic targets of gout, as well as the composition and corresponding therapeutic targets of this drug pair. In order to reveal the rationality of DS, we established the topological network analysis of TCM components and targets of DS, which provided a potential synergistic mechanism for the treatment of gout by DS. The biological network analytical approach applied in the research may be significant for the exploring of functionary effect of TCM.

\section{Materials And Methods}

\subsection{Data Preparation}

\subsubsection{Building database of ingredients of DS}

All the chemical ingredients' data of DH and SG were downloaded from Traditional Chinese Medicine Systems Pharmacology Database (TCMSP) (http://lsp.nwu.edu.cn/tcmsp.php) (Yu et al. 2020). The TCMSP database provides pharmacokinetic information for each compound. Therefore, users can select compounds with analogous characteristics to drugs and ADME (absorption, distribution, metabolism, excretion) for further research (Nielsen et al. 2017).

\subsubsection{Screening of active compounds}

Through the integration of oral bioavailability (OB) and drug-likeness (DL), the active components of DH and SG were screened. DL is useful in describing the pharmacokinetics and peculiarities of compounds, such as solvability and chemical stability. Usually, the inclusion criteria of "drug-like" compounds in TCM is 0.18 (Luo et al. 2020). OB is the ratio of oral drugs absorbed into blood circulation. Because the low OB level is the main cause for the transformation of TCM into curative medicine, it is very important to carry out OB screening criteria. According to the literature and suggestions, the $\mathrm{OB} \geq 30 \%$ and $\mathrm{DL} \geq 0.18$ of the 
compounds were set as screening conditions to screen the compounds with high activity in TCMSP (Du et al. 2017). The ingredients meeting above-mentioned both criteria will be conserved for further study.

\subsubsection{TCM-associated target prediction}

Combined with three databases, the related indicators of active ingredients in DH and SG were synthetically predicted. GeneCards database (Wang et al. 2019) (http://www.genecards.org/) automatically integrates gene-centric data from 125 network sources, while BATMAN-TCM (http://bionet.ncpsb.org/batman-tcm) (Tong et al. 2018) ranks potential drug-target combinations based on their similarities to known drug-target relations. STITCH database (http://stitch.embl.de/) (Tran et al. 2017) integrates many experimental and manual evidence sources with data mining and interactive prediction. Firstly, the active ingredients were input into gene card, Batman traditional Chinese medicine and STITCH respectively. Then, duplicate and unified names are deleted from the targets obtained by the above three tools. It is noteworthy that only the goals of Homo sapiens are got for further research.

\subsection{4 gout-associated target prediction}

Through OMIM database (http://omim.org/) (Li et al. 2012), TTD database (http://systemsdock.unit.oist.jp/iddp/home/index) (Tran 2017) and PharmGkb database (http://geneticassociationdb.nih.gov/) (Chen et al. 2018), the keywords "gout" and "hyperuricemia" were retrieved. Also, the related literatures were searched for the reported gout-related genes. After removing duplicate and false positive genes, 98 gout-related target genes were finally collected.

\subsubsection{Construction of protein-protein interaction (PPI) network}

In order to illustrate the role of target proteins at the system level, Bisogenet plug-ins in Cytoscape 3.5.1 software (http://www.cytoscape.org/) (Cox et al. 2018) were used to construct component target PPI and disease target PPI, respectively. Topological analysis of them and screening of core targets were carried out.

\subsubsection{Enrichment analysis of Kyoto Encyclopedia of Genes and Genomes (KEGG) pathway}

KEGG pathway enrichment analysis of proteins in PPI network was carried out by using David database (https://david.ncifcrf.gov/) (Pérezvalencia et al. 2018; Giulietti et al. 2017). The role of target proteins in signaling pathway of DS compounds was explained, and the main action pathways of DS drug pairs in gout were obtained. The enrichment analysis results were visualized by Omicshare software (http://www.omicshare.com/tools/index.php/).

\subsubsection{Network construction and node screening}


The different targets from DH, SG and gout were submitted to Agilent Literature Search Software 2.78 (Liu et al. 2015). Based on the human targets, we set "Max Engine Matches" as 10 and researched in the full text. After that, the protein-protein interaction meshwork was visualized by Cytoscape 3.5.1 software.

\section{Results And Discussion}

\subsection{Main active components of DS}

A total of 85 active ingredients in DS were collected from TCMP database, including 75 ingredients of DH and 10 ingredients of SG. In this study, 16 active compounds from 85 compounds met both the criteria, OB $\geq 30 \%$ and $\mathrm{DL} \geq 0.18$ (Table 1). Experiments have proved that some components of TCM have pharmacological activities. For example, diosgenin $(\mathrm{OB}=80.88, \mathrm{DL}=0.81)$ plays a momentous therapeutic part in anti-inflammation, anti-hyperlipidemia, anti-cancer and liver protection (Sethi et al. 2018). Neoastilbin $(\mathrm{OB}=40.54, \mathrm{DL}=0.74)$ has significant selective immunosuppressive, hypolipidemic, hypoglycemic and anticancer effects (Singh et al. 2016).

\subsection{Complex network construction and analysis}

On the basis of the data in Table 1, network is built. According to existing proof, we get that DS's traditional effects have something to do with contemporary pharmacology, which illustrates that some targets are hit by diverse compounds. Therefore, we can roughly understand the relationship between the drug active compounds and the action targets from the target network. This shows that DS's compounds may affect on these targets in phase and thus take therapeutic effect in else besides gout, which invisibly show DS's feature of multicompound-multitarget-multidisease. Its possible functions may be explored by the network (Fig. 1).

\subsection{KEGG pathway enrichment analysis}

KEGG pathway enrichment analysis of common core target proteins screened by DS was carried out using DAVID database, $90.6 \%$ of which were analyzed, and 97 signaling pathways were obtained. Screening was performed with $P$ values $<0.01$ and FDR $<0.05$. The results of 24 pathways are described in Table 2 , which indicate that the active ingredients of DS may be used to treat gout by acting on these signaling pathways. Omicshare database was used to visualize the results of enrichment analysis (Fig. 2). On the basis of KEGG analysis result, these targets are very much related to the Neuroactive ligand-receptor interaction (Fold Enrichment $=6 ; P<0.001$ ), Calcium signaling pathway (Fold Enrichment $=5.4 ; P<0.001$ ), Morphine addiction (Fold Enrichment $=7.9 ; P<0.001$ ), Nicotine addiction (Fold Enrichment $=11.1 ; P<0.001$ ) and so on. This suggests that DS can regulate many metabolic signaling pathways and play a considerable regulatory part in the pathophysiological processes of metabolic and immune reaction. 
Table 2

KEGG pathway enrichment results of DS

\begin{tabular}{|c|c|c|c|c|c|c|c|c|}
\hline Term & Count & $\%$ & $\begin{array}{l}\text { P- } \\
\text { Value }\end{array}$ & $\begin{array}{l}\text { Fold } \\
\text { Enrichment }\end{array}$ & Bonferroni & Benjamini & FDR & $\begin{array}{l}\text { Fisher } \\
\text { Exact }\end{array}$ \\
\hline $\begin{array}{l}\text { Neuroactive } \\
\text { ligand-receptor } \\
\text { interaction }\end{array}$ & 79 & 0.1 & $\begin{array}{l}8.70 \mathrm{E}- \\
41\end{array}$ & 6 & $2.00 \mathrm{E}-38$ & 2.00E-38 & $\begin{array}{l}1.10 \mathrm{E}- \\
37^{-}\end{array}$ & $\begin{array}{l}1.10 \mathrm{E}- \\
41\end{array}$ \\
\hline $\begin{array}{l}\text { Calcium } \\
\text { signaling } \\
\text { pathway }\end{array}$ & 46 & 0.1 & $\begin{array}{l}3.10 \mathrm{E}- \\
21\end{array}$ & 5.4 & 7.30E-19 & 3.70E-19 & $\begin{array}{l}4.00 \mathrm{E}- \\
18\end{array}$ & $\begin{array}{l}4.60 \mathrm{E}- \\
22\end{array}$ \\
\hline $\begin{array}{l}\text { Morphine } \\
\text { addiction }\end{array}$ & 33 & 0 & $\begin{array}{l}1.30 \mathrm{E}- \\
20\end{array}$ & 7.9 & 3.00E-18 & $1.00 \mathrm{E}-18$ & $\begin{array}{l}1.70 \mathrm{E}- \\
17\end{array}$ & $\begin{array}{l}1.10 \mathrm{E}- \\
21\end{array}$ \\
\hline $\begin{array}{l}\text { Nicotine } \\
\text { addiction }\end{array}$ & 21 & 0 & $\begin{array}{l}1.30 \mathrm{E}- \\
16\end{array}$ & 11.1 & 2.60E-14 & $6.40 \mathrm{E}-15$ & $\begin{array}{l}1.40 \mathrm{E}- \\
13\end{array}$ & $\begin{array}{l}6.70 \mathrm{E}- \\
18\end{array}$ \\
\hline $\begin{array}{l}\text { GABAergic } \\
\text { synapse }\end{array}$ & 28 & 0 & $\begin{array}{l}2.90 \mathrm{E}- \\
16\end{array}$ & 7.1 & 7.80E-14 & $1.60 \mathrm{E}-14$ & $\begin{array}{l}4.30 \mathrm{E}- \\
13\end{array}$ & $\begin{array}{l}2.90 \mathrm{E}- \\
17\end{array}$ \\
\hline $\begin{array}{l}\text { Retrograde } \\
\text { endocannabinoid } \\
\text { signaling }\end{array}$ & 29 & 0 & $\begin{array}{l}5.30 \mathrm{E}- \\
15\end{array}$ & 6.2 & $1.20 \mathrm{E}-12$ & $2.00 \mathrm{E}-13$ & $\begin{array}{l}6.70 \mathrm{E}- \\
12\end{array}$ & $\begin{array}{l}6.90 \mathrm{E}- \\
16\end{array}$ \\
\hline $\begin{array}{l}\text { CAMP signaling } \\
\text { pathway }\end{array}$ & 39 & 0.1 & $\begin{array}{l}1.10 \mathrm{E}- \\
14\end{array}$ & 4.4 & 2.60E-12 & 3.70E-13 & $\begin{array}{l}1.40 \mathrm{E}- \\
11\end{array}$ & $\begin{array}{l}2.10 \mathrm{E}- \\
15\end{array}$ \\
\hline $\begin{array}{l}\text { Serotonergic } \\
\text { synapse }\end{array}$ & 30 & 0 & $\begin{array}{l}1.40 \mathrm{E}- \\
14\end{array}$ & 5.7 & 3.40E-12 & 4.20E-13 & $\begin{array}{l}1.80 \mathrm{E}- \\
11\end{array}$ & $\begin{array}{l}1.90 \mathrm{E}- \\
15\end{array}$ \\
\hline $\begin{array}{l}\text { CGMP-PKG } \\
\text { signaling } \\
\text { pathway }\end{array}$ & 30 & 0 & $\begin{array}{l}6.90 \mathrm{E}- \\
11\end{array}$ & 4.2 & 1.60E-08 & 1.80E-09 & $\begin{array}{l}8.90 \mathrm{E}- \\
08\end{array}$ & $\begin{array}{l}1.40 \mathrm{E}- \\
11\end{array}$ \\
\hline $\begin{array}{l}\text { Adrenergic } \\
\text { signaling in } \\
\text { cardiomyocytes }\end{array}$ & 26 & 0 & $\begin{array}{l}1.30 \mathrm{E}- \\
09\end{array}$ & 4.2 & 3.00E-07 & 3.00E-08 & $\begin{array}{l}1.60 \mathrm{E}- \\
06\end{array}$ & $\begin{array}{l}2.50 \mathrm{E}- \\
10\end{array}$ \\
\hline $\begin{array}{l}\text { MAPK signaling } \\
\text { pathway }\end{array}$ & 35 & 0.1 & $\begin{array}{l}8.90 \mathrm{E}- \\
09\end{array}$ & 3 & $2.10 \mathrm{E}-06$ & 1.90E-07 & $\begin{array}{l}1.10 \mathrm{E}- \\
05\end{array}$ & $\begin{array}{l}2.60 \mathrm{E}- \\
09\end{array}$ \\
\hline $\begin{array}{l}\text { Dopaminergic } \\
\text { synapse }\end{array}$ & 23 & 0 & $\begin{array}{l}4.60 \mathrm{E}- \\
08\end{array}$ & 4 & 1.10E-05 & $9.00 \mathrm{E}-07$ & $\begin{array}{l}5.90 \mathrm{E}- \\
05\end{array}$ & $\begin{array}{l}9.90 \mathrm{E}- \\
09\end{array}$ \\
\hline $\begin{array}{l}\text { Oxytocin } \\
\text { signaling } \\
\text { pathway }\end{array}$ & 24 & 0 & $\begin{array}{l}1.10 \mathrm{E}- \\
07\end{array}$ & 3.7 & 2.50E-05 & $1.90 \mathrm{E}-06$ & $\begin{array}{l}1.40 \mathrm{E}- \\
04\end{array}$ & $\begin{array}{l}2.50 \mathrm{E}- \\
08\end{array}$ \\
\hline $\begin{array}{l}\text { Cholinergic } \\
\text { synapse }\end{array}$ & 20 & 0 & $\begin{array}{l}3.60 \mathrm{E}- \\
07\end{array}$ & 4 & 8.40E-05 & $6.00 \mathrm{E}-06$ & $\begin{array}{l}4.60 \mathrm{E}- \\
04\end{array}$ & $\begin{array}{l}7.60 \mathrm{E}- \\
08\end{array}$ \\
\hline Renin secretion & 15 & 0 & $\begin{array}{l}9.90 \mathrm{E}- \\
07\end{array}$ & 5 & 2.30E-04 & 1.50E-05 & $\begin{array}{l}1.30 \mathrm{E}- \\
03\end{array}$ & $\begin{array}{l}1.60 \mathrm{E}- \\
07\end{array}$ \\
\hline $\begin{array}{l}\text { Pathways in } \\
\text { cancer }\end{array}$ & 41 & 0.1 & $\begin{array}{l}1.10 \mathrm{E}- \\
06\end{array}$ & 2.3 & $2.70 \mathrm{E}-04$ & 1.70E-05 & $\begin{array}{l}1.50 \mathrm{E}- \\
03\end{array}$ & $\begin{array}{l}4.70 \mathrm{E}- \\
07\end{array}$ \\
\hline
\end{tabular}




\begin{tabular}{|c|c|c|c|c|c|c|c|c|}
\hline Term & Count & $\%$ & $\begin{array}{l}\text { P- } \\
\text { Value }\end{array}$ & $\begin{array}{l}\text { Fold } \\
\text { Enrichment }\end{array}$ & Bonferroni & Benjamini & FDR & $\begin{array}{l}\text { Fisher } \\
\text { Exact }\end{array}$ \\
\hline $\begin{array}{l}\text { Chagas disease } \\
\text { (American } \\
\text { trypanosomiasis) }\end{array}$ & 19 & 0 & $\begin{array}{l}2.80 \mathrm{E}- \\
06\end{array}$ & 3.7 & $6.60 \mathrm{E}-04$ & 3.90E-05 & $\begin{array}{l}3.70 \mathrm{E}- \\
03\end{array}$ & $\begin{array}{l}6.70 \mathrm{E}- \\
07\end{array}$ \\
\hline $\begin{array}{l}\text { African } \\
\text { trypanosomiasis }\end{array}$ & 11 & 0 & $\begin{array}{l}3.50 \mathrm{E}- \\
06\end{array}$ & 6.6 & 8.20E-04 & 4.60E-05 & $\begin{array}{l}4.50 \mathrm{E}- \\
03\end{array}$ & $\begin{array}{l}4.00 \mathrm{E}- \\
07\end{array}$ \\
\hline $\begin{array}{l}\text { Type II diabetes } \\
\text { mellitus }\end{array}$ & 12 & 0 & $\begin{array}{l}5.30 \mathrm{E}- \\
06\end{array}$ & 5.7 & $1.20 \mathrm{E}-03$ & $6.60 \mathrm{E}-05$ & $\begin{array}{l}6.80 \mathrm{E}- \\
03\end{array}$ & $\begin{array}{l}7.40 \mathrm{E}- \\
07\end{array}$ \\
\hline $\begin{array}{l}\text { Aldosterone } \\
\text { synthesis and } \\
\text { secretion }\end{array}$ & 15 & 0 & $\begin{array}{l}9.40 \mathrm{E}- \\
06\end{array}$ & 4.2 & $2.20 \mathrm{E}-03$ & 1.10E-04 & $\begin{array}{l}1.20 \mathrm{E}- \\
02\end{array}$ & $\begin{array}{l}1.90 \mathrm{E}- \\
06\end{array}$ \\
\hline Insulin secretion & 15 & 0 & $\begin{array}{l}1.50 \mathrm{E}- \\
05\end{array}$ & 4.1 & $3.40 \mathrm{E}-03$ & 1.60E-04 & $\begin{array}{l}1.90 \mathrm{E}- \\
02\end{array}$ & $\begin{array}{l}3.10 \mathrm{E}- \\
06\end{array}$ \\
\hline $\begin{array}{l}\text { Vascular smooth } \\
\text { muscle } \\
\text { contraction }\end{array}$ & 18 & 0 & $\begin{array}{l}2.10 \mathrm{E}- \\
05\end{array}$ & 3.3 & 4.90E-03 & 2.20E-04 & $\begin{array}{l}2.70 \mathrm{E}- \\
02\end{array}$ & $\begin{array}{l}5.60 \mathrm{E}- \\
06\end{array}$ \\
\hline $\begin{array}{l}\text { Dilated } \\
\text { cardiomyopathy }\end{array}$ & 15 & 0 & $\begin{array}{l}2.60 \mathrm{E}- \\
05\end{array}$ & 3.9 & $6.00 \mathrm{E}-03$ & 2.60E-04 & $\begin{array}{l}3.30 \mathrm{E}- \\
02\end{array}$ & $\begin{array}{l}5.70 \mathrm{E}- \\
06\end{array}$ \\
\hline $\begin{array}{l}\text { Amphetamine } \\
\text { addiction }\end{array}$ & 13 & 0 & $\begin{array}{l}3.70 \mathrm{E}- \\
05\end{array}$ & 4.3 & $8.50 \mathrm{E}-03$ & $3.60 \mathrm{E}-04$ & $\begin{array}{l}4.70 \mathrm{E}- \\
02\end{array}$ & $\begin{array}{l}7.20 \mathrm{E}- \\
06\end{array}$ \\
\hline
\end{tabular}

\subsection{Network construction and node screening}

Network formation was automatically completed through retrieval by Agilent Literature Retrieval. The topological parameters of $\mathrm{DH}, \mathrm{SG}$ and gout show that node-degree distribution submits to the power law distribution. As displayed in Fig. 3, the drug pair shares 9 targets (NLRP3, STS, EPHB2, PRKAA1, ROS1, SLC22A12, ATP8A2, IRF6 and P2RX7) with gout.

\section{Discussion}

Gout is a kind of hyperuricemia caused by the increased synthesis or decreased excretion of uric acid due to the disorder of purine metabolism (Hutton et al. 2018). When the level of uric acid in blood is too high, uric acid is deposited in joints, soft tissues, cartilages and kidneys in the form of sodium salts, causing inflammatory reaction of tissues (Vazquezmellado et al. 2018).

In recent years, more and more attention has been paid to the use of traditional Chinese medicine and natural medicine in the treatment of gout, which has the advantages of definite efficacy, safety and less adverse reactions (Chow et al. 2019). It is believed that damp-heat, phlegm turbidity, blood stasis and insufficiency of liver, spleen and kidney are the main causes and pathogenesis of gout (Tomioka et al. 
2016). Damp-heat gathering, stasis-heat accumulation, Phlegm-turbidity block and liver-kidney Yin deficiency are the basic syndromes of gout (Liang et al. 2017; Wu et al. 2014). DH and SG are Chinese medicine pairs that are often used for gout treatment (Xie et al. 2017). It has been found that $70 \%$ ethanol extract of DH can raise the expression of organic anion transporter 1 (OAT1), organic anion transporter 2 (OAT2) genes and proteins in animal kidneys, and transfer to a lower expression of urate transporter 1 (URAT1) genes and proteins (Pernthaler 2017; Nałęcz 2017). Total saponins of DH can decrease serum uric acid level in a dose-dependent manner, increase uric acid concentration and uric acid secretion, creatinine secretion, uric acid excretion fraction, glomerular filtration uric acid secretion (Wang et al. 2017; Njoum \& Kyriacou 2017). The water extract of DH can down-regulate the gene expression of monocyte chemoattractant protein-1 (MCP-1) in serum and tumor necrosis factor-alpha (TNF-a), intercellular adhesion molecule-1 (ICAM-1), vascular cell adhesion molecule-1 (VCAM-1) in kidney of rats with hyperuricemia and improve the anti-inflammatory effect of the body (Wu et al. 2019; Mahmoud et al. 2017). SG can inhibit xanthione oxidase (XOD) to reduce uric acid, alleviate oxidative stress induced by hyperuricemia, play an anti-inflammatory role, and protect kidney function (Xie et al. 2017; He et al. 2016).

Clinical studies have confirmed that IL-1 $\beta$ is an inflammatory factor in synovial tissue of articular cavity during the pathological process of gouty arthritis (Claude-Taupin et al. 2018; Jesus \& Goldbach-Mansky 2014). The activation of NLRP3 inflammatory bodies and the release of IL-1 $\beta$ plays a major part in the progress of gout (He et al. 2012). MSU plays an important role in the regulation of NLRP3 gene and its expression (Yan et al. 2013; Haneklaus et al. 2013). MSU crystals can be recognized by NLRP3, which can increase the number of monocyte macrophages to phagocytize MSU crystals, destroy cell lysosomes and other organelles, release histamine and chemokines, cause local vascular dilation, leukocyte aggregation and other inflammatory reactions, and lead to acute gouty arthritis (Lee et al. 2016; Orlowski et al. 2016). NLRP3 can also form highly ordered oligomers of NLRP3 protein through ATP polymerization, and recruit Caspase 1 (CASP1) to form inflammatory bodies of NLRP3 to produce activated CASP1 (Wang et al. 2017; Duncan et al. 2018). Activated CASP1 can cleave the inactive precursor of IL-1 $\beta$ at 116 aspartic acid sites, and form activated mature IL-1 $\beta$ secreted to the outside of the cell, resulting in inflammation and immune response (Feng et al. 2017; Clipman et al. 2018; Afonina et al. 2017). P2RX7 gene plays an important role in monocytes and innate immunity, including Toll-like receptor-mediated Nuclear factor-kappa B (NF-KB) pathway and NALP3 inflammatory body pathway (Kim et al. 2018; Notomi et al. 2011). P2RX7 may be associated with the risk of primary gout in Chinese Han male population (Ying et al. 2017). When extracellular ATP concentration changes dramatically, P2X7 receptors are activated and opened, resulting in $\mathrm{K}^{+}$outflow and $\mathrm{Na}^{+}$and $\mathrm{Ca}^{2+}$ influx, which further leads to the release and activation of NLRP3 inflammatory bodies leading to acute gout attacks (Giacovazzo et al. 2018; Di Virgilio et al. 2017; Paredes et al. 2018). Some studies have pointed out that STS can inhibit MSU crystal-induced interleukin (IL) - $1 \beta$ secretion in primary human macrophages (Karmegam and Shetty 2017; Zhang et al. 2017; Henry et al. 2014). Also, STS decreases IL-1 $\beta$ in supernatants upon absent in melanoma 2 (AIM2) activation (Barnes 2018). IRF6 regulates NLRP3 inflammatory bodies, induces degradation of extracellular matrix of chondrocytes, and plays a considerable part in cartilage destruction of gouty arthritis diseases (Kumari et al. 2018). NADPH oxidase activates ROS1 to produce enhanced trigger redox sensitive pathways (Joo \& Rhie 2017). Hyperuricemia increases ROS1 production through activation of NADPH oxidase and xanthine oxidase 
(Roskoski 2017). ATP8A2 promotes the chemotaxis of inflammatory cells by recognizing CX3C chemokine receptor 1 (CX3CR1) and acts a momentous part in the pathological process of inflammatory reaction including ROS1 aggregation and adhesion (Wang et al. 2018; Coleman et al. 2012). EPHB2 is involved in the regulation of $T$ cell migration and monocyte activation (Alapin et al. 2020). Some studies have shown that EPHB2 has some effects on the proliferation of vascular smooth muscle cells and the secretion of ROS1 to emerge redox sensitive pathways (Pozniak et al. 2016; Min et al. 2016; Gaitanos et al. 2016). Activated PRKAA1 can enhance inhibitor of NF-KB, a isoform (IKBa) expression from cytoplasm to nucleus and regulate the activity of NF-KB pathway to act on NLRP3 inflammatory bodies (Krishan et al. 2014). SLC22A12 is a uric acid anion exchanger of uric acid-converting protein gene in kidney, which can regulate the concentration of uric acid in human blood (Vázquez-Mellado et al. 2017; Shima et al. 2006; Kuriyama 2020). Experiments showed that the reabsorption of uric acid by kidneys of mice knocked out SLC22A12 gene by gene knockout test was significantly reduced (Arakawa et al. 2020).

\section{Conclusion}

In this study, in order to better identify the drug efficacy of DS, we conducted integrated component prediction and DS target pathway analysis strategy using network pharmacology. The method mins and extracts the potential synergy effect of DH and SG from the perspective of interaction network. This study found that gout and DS share common targets such as NLRP3, STS, EPHB2, PRKAA1, ROS1, SLC22A12, ATP8A2, IRF6 and P2RX7, which may be the key points for DS to treat gout. But clinical and experimental trials require further validation.

\section{Declarations}

\section{Data Availability}

The data used to support this study are included within this article.

\section{Disclosure}

Wei Liu, and Wenjia Zhao are the co-first authors.

\section{Competing Interests}

The authors declare that there is no conflict of interests regarding the publication of this paper.

\section{Authors' Contributions}

Liu Wei is responsible for the study concept, design, and literature searching; Liu Wei and Wu Yuan-hao are responsible for data analysis and interpretation; Wu Yuan-hao and Zhao Wen-jia carried out extensive 
revision of the manuscript; all authors participated in the analysis and interpretation of data and approved the final paper. The authors declare that all data were generated in-house and that no paper mill was used.

\section{Acknowledgments}

This work is supported by the National Natural Science Foundation of China (Grant no. 81673927) and Tianjin Key Laboratory of Translational Research of TCM Prescription and Syndrome.

\section{References}

1. Afonina IS, Zhong Z, Karin M, Beyaert R (2017) Limiting inflammation-the negative regulation of NF-KB and the NLRP3 inflammasome. Nat Immunol 18(8): 861-869. https://doi.org/10.1038/ni.3772

2. Alapin J M, Dines M, Lamprecht $R$ (2020) EphB2 receptor forward signaling is needed for normal longterm memory formation in aged mice. Neurobiol Aging 86: 11-15.

https://doi.org/10.1016/j.neurobiolaging.2019.10.019

3. Arakawa H, Amezawa N, Kawakatsu Y, Tamai I (2020) Renal Reabsorptive Transport of Uric Acid Precursor Xanthine by URAT1 and GLUT9. Biol Pharm Bull 43(11): 1792-1798. https://doi.org/10.1248/bpb.b20-00597

4. Barnes C S (2018) Impact of Climate Change on Pollen and Respiratory Disease. Curr Allergy Asthma Rep 18(11): 59. https://doi.org/10.1007/s11882-018-0813-7

5. Chen Z, Han Y, Song C, Wei H, Chen Y, Huang K, Li S, Ma D, Wang S, Wang J, Lu Q (2017) Systematic review and meta-analysis of the prognostic significance of microRNAs in cervical cancer. Oncotarget 9(24): 17141-17148. https://doi.org/10.18632/oncotarget.23839

6. Chow H C, So T H, Choi H, Lam K O (2019). Literature Review of Traditional Chinese Medicine HerbsInduced Liver Injury From an Oncological Perspective With RUCAM. Integr Cancer Ther 18: 1534735419869479. https://doi.org/10.1177/1534735419869479

7. Claude-Taupin A, Bissa B, Jia J, Gu Y, Deretic V (2018) Role of autophagy in IL-1 $\beta$ export and release from cells. Semin Cell Dev Biol 83: 36-41. https://doi.org/10.1016/j.semcdb.2018.03.012

8. Clipman S J, Henderson-Frost J, Fu K Y, Bern C, Flores J, Gilman R H (2018) Genetic association study of NLRP1, CARD, and CASP1 inflammasome genes with chronic Chagas cardiomyopathy among Trypanosoma cruzi seropositive patients in Bolivia. PloS one 13(2): e0192378. https://doi.org/10.1371/journal.pone.0192378

9. Coleman J A, Vestergaard A L, Molday R S, Vilsen B, Andersen J P (2012) Critical role of a transmembrane lysine in aminophospholipid transport by mammalian photoreceptor P4-ATPase ATP8A2. Proc Natl Acad Sci U S A 109(5): 1449-1454. https://doi.org/10.1073/pnas.1108862109

10. Cox D G, Heudel P E, Henry J, Pivot X (2018) Transmission of breast cancer polygenic risk based on single nucleotide polymorphisms. Breast 41: 14-18. https://doi.org/10.1016/j.breast.2018.06.006

11. Di Virgilio F, Dal Ben D, Sarti A C, Giuliani A L, Falzoni S (2017) The P2X7 Receptor in Infection and Inflammation. Immunity 47(1): 15-31. https://doi.org/10.1016/j.immuni.2017.06.020 
12. Doghramji P P, Fermer S, Wood R, Morlock R, Baumgartner S (2016) Management of gout in the real world: current practice versus guideline recommendations. Postgrad Med 128(1): 106-114. https://doi.org/10.1080/00325481.2016.1114878

13. Du G Q, Shao Z B, Wu J, Yin W J, Li S H, Wu J, Weisel R D, Tian J W, Li R K (2017) Targeted myocardial delivery of GDF11 gene rejuvenates the aged mouse heart and enhances myocardial regeneration after ischemia-reperfusion injury. Basic Res Cardiol 112(1): 7. https://doi.org/10.1007/s00395-016-0593-y

14. Duncan J A, Canna S W (2018) The NLRC4 Inflammasome. Immunol Rev 281(1): 115-123. https://doi.org/10.1111/imr.12607

15. Engel B, Just J, Bleckwenn M, Weckbecker K (2017) Treatment Options for Gout. Dtsch Arztebl Int 114(13): 215-222. https://doi.org/10.3238/arztebl.2017.0215

16. Feng X, Yu Y, He S, Cheng J, Gong Y, Zhang Z, Yang X, Xu B, Liu X, Li C Y, Tian L, Huang Q (2017) Dying glioma cells establish a proangiogenic microenvironment through a caspase 3 dependent mechanism. Cancer Lett 385: 12-20. https://doi.org/10.1016/j.canlet.2016.10.042

17. Gaitanos T N, Koerner J, Klein R (2016) Tiam-Rac signaling mediates trans-endocytosis of ephrin receptor EphB2 and is important for cell repulsion. J Cell Biol 214(6): 735-752. https://doi.org/10.1083/jcb.201512010

18. Giacovazzo G, Apolloni S, Coccurello R (2018) Loss of P2X7 receptor function dampens whole body energy expenditure and fatty acid oxidation. Purinergic Signal 14(3): 299-305. https://doi.org/10.1007/s11302-018-9610-y

19. Giulietti M, Occhipinti G, Principato G, Piva F (2017) Identification of candidate miRNA biomarkers for pancreatic ductal adenocarcinoma by weighted gene co-expression network analysis. Cell Oncol 40(2): 181-192. https://doi.org/10.1007/s13402-017-0315-y

20. Haneklaus M, O'Neill L A, Coll R C (2013) Modulatory mechanisms controlling the NLRP3 inflammasome in inflammation: recent developments. Curr Opin Immunol 25(1), 40-45. https://doi.org/10.1016/j.coi.2012.12.004

21. He J, Yang Y, Peng D Q (2012) Monosodium urate (MSU) crystals increase gout associated coronary heart disease (CHD) risk through the activation of NLRP3 inflammasome. Int J Cardiol 160(1): 72-73. https://doi.org/10.1016/j.ijcard.2012.05.083

22. He X, Yi T, Tang Y, Xu J, Zhang J, Zhang Y, Dong L, Chen H (2016) Assessing the quality of Smilacis Glabrae Rhizoma (Tufuling) by colormetrics and UPLC-Q-TOF-MS. Chin Med 11: 33. https://doi.org/10.1186/s13020-016-0104-y

23. Henry T D, Satran D, Jolicoeur E M (2014) Treatment of refractory angina in patients not suitable for revascularization. Nat Rev Cardiol 11(2): 78-95. https://doi.org/10.1038/nrcardio.2013.200

24. Hutton J, Fatima T, Major T J, Topless R, Stamp L K, Merriman T R, Dalbeth N (2018) Mediation analysis to understand genetic relationships between habitual coffee intake and gout. Arthritis Res Ther 20(1): 135. https://doi.org/10.1186/s13075-018-1629-5

25. Janssen C A, Jansen T, Oude Voshaar M, Vonkeman H E, van de Laar M (2017) Quality of care in gout: a clinical audit on treating to the target with urate lowering therapy in real-world gout patients. Rheumatol Int 37(9): 1435-1440. https://doi.org/10.1007/s00296-017-3777-3 
26. Jesus A A, Goldbach-Mansky R (2014) IL-1 blockade in autoinflammatory syndromes. Annual review of medicine, 65: 223-244. https://doi.org/10.1146/annurev-med-061512-150641

27. Johansson E, Brache V, Alvarez F, Faundes A, Cochon L, Ranta S, Lovern M, Kumar N (2002) Pharmacokinetic study of different dosing regimens of levonorgestrel for emergency contraception in healthy women. Hum Reprod 17(6): 1472-1476. https://doi.org/10.1093/humrep/17.6.1472

28. Joo Y, Rhie J (2017) The relationship between emotional labor status and workplace violence among toll collectors. Ann Occup Environ Med 29: 34. https://doi.org/10.1186/s40557-017-0193-9

29. Karmegam S, Shetty A (2017) Calciphylaxis after parathyroidectomy. Hemodial Int 21(S2): S62-S66. https://doi.org/10.1111/hdi.12599

30. Kim J E, Ko A R, Hyun H W, Min S J, Kang T C (2018) P2RX7-MAPK1/2-SP1 axis inhibits MTOR independent HSPB1-mediated astroglial autophagy. Cell Death Dis 9(5): 546. https://doi.org/10.1038/s41419-018-0586-x

31. Krishan S, Richardson D R, Sahni S (2014) Gene of the month. AMP kinase (PRKAA1). J Clin Pathol 67(9): 758-763. https://doi.org/10.1136/jclinpath-2014-202422

32. Kumari P K, Ali A, Singh S K, Chaurasia A, Raman R (2018) Genetic heterogeneity in Van der Woude syndrome: identification of NOL4 and IRF6 haplotype from the noncoding region as candidates in two families. J Genet 97(1): 275-285. https://doi.org/10.1007/s12041-018-0903-2

33. Kuriyama S (2020) Dotinurad: a novel selective urate reabsorption inhibitor as a future therapeutic option for hyperuricemia. Clin Exp Nephrol 24(Suppl 1): 1-5. https://doi.org/10.1007/s10157-01901811-9

34. Lee H E, Yang G, Kim N D, Jeong S, Jung Y, Choi J Y, Park H H, Lee J Y (2016) Targeting ASC in NLRP3 inflammasome by caffeic acid phenethyl ester: a novel strategy to treat acute gout. Sci Rep 6: 38622. https://doi.org/10.1038/srep38622

35. Li Z, Ying B, Liu X, Zhang X, Yu H (2012) An examination of the OMIM database for associating mutation to a consensus reference sequence. Protein Cell 3(3): 198-203.

https://doi.org/10.1007/s13238-012-2037-2

36. Liang C, Ju W, Pei S, Tang Y, Xiao Y (2017) Pharmacological Activities and Synthesis of Esculetin and Its Derivatives: A Mini-Review. Molecules 22(3): 387. https://doi.org/10.3390/molecules22030387

37. Lin J, Zhu J, Wang Y, Zhang N, Gober H J, Qiu X, Li D, Wang L (2017) Chinese single herbs and active ingredients for postmenopausal osteoporosis: From preclinical evidence to action mechanism. Biosci Trends 11(5): 496-506. https://doi.org/10.5582/bst.2017.01216

38. Liu Y, Hu X, Han C, Wang L, Zhang X, He X, Lu X (2015) Targeting tumor suppressor genes for cancer therapy. Bioessays 37(12): 1277-1286. https://doi.org/10.1002/bies.201500093

39. Luo T T, Lu Y, Yan S K, Xiao X, Rong X L, Guo J (2020) Network Pharmacology in Research of Chinese Medicine Formula: Methodology, Application and Prospective. Chin J Integr Med 26(1): 72-80. https://doi.org/10.1007/s11655-019-3064-0

40. Mahmoud A M, Wilkinson F L, McCarthy E M, Moreno-Martinez D, Langford-Smith A, Romero M, Duarte J, Alexander M Y (2017) Endothelial microparticles prevent lipid-induced endothelial damage via 
Akt/eNOS signaling and reduced oxidative stress. Faseb J 31(10): 4636-4648.

https://doi.org/10.1096/fj.201601244RR

41. Nałęcz K A (2017) Solute Carriers in the Blood-Brain Barier: Safety in Abundance. Neurochemical research 42(3): 795-809. https://doi.org/10.1007/s11064-016-2030-x

42. Nielsen J (2017) Systems Biology of Metabolism: A Driver for Developing Personalized and Precision Medicine. Cell Metab 25(3): 572-579. https://doi.org/10.1016/j.cmet.2017.02.002

43. Njoum H, Kyriacou P A (2017). Photoplethysmography for the Assessment of Haemorheology. Sci Rep 7(1): 1406. https://doi.org/10.1038/s41598-017-01636-0

44. Notomi S, Hisatomi T, Kanemaru T, Takeda A, Ikeda Y, Enaida H, Kroemer G, Ishibashi T (2011) Critical involvement of extracellular ATP acting on P2RX7 purinergic receptors in photoreceptor cell death. Am J Pathol 179(6): 2798-2809. https://doi.org/10.1016/j.ajpath.2011.08.035

45. Orlowski G M, Colbert J D, Sharma S, Bogyo M, Robertson S A, Rock K L (2015) Multiple Cathepsins Promote Pro-IL-1 $\beta$ Synthesis and NLRP3-Mediated IL-1 $\beta$ Activation. J Immunol 195(4): 1685-1697. https://doi.org/10.4049/jimmunol.1500509

46. Paredes C, Li S, Chen X, Coddou C (2018) Divalent metal modulation of Japanese flounder (Paralichthys olivaceus) purinergic P2X7 receptor. FEBS open bio 8(3): 383-389. https://doi.org/10.1002/22115463.12375

47. Pérezvalencia J A, Prosdocimi F, Cesari I M, da Costa I R, Furtado C, Agostini M, Rumjanek F D (2018) Angiogenesis and evading immune destruction are the main related transcriptomic characteristics to the invasive process of oral tongue cancer. Sci Rep 8(1): 2007. https://doi.org/10.1038/s41598-01719010-5

48. Pernthaler $\mathrm{J}$ (2017) Competition and niche separation of pelagic bacteria in freshwater habitats. Environ Microbiol 19(6): 2133-2150. https://doi.org/10.1111/1462-2920.13742

49. Pillinger M H, Bangalore S, Klein A B, Baumgartner S, Morlock R (2017) Cardiovascular Disease and Gout: Real-World Experience Evaluating Patient Characteristics, Treatment Patterns, and Health Care Utilization. J Manag Care Spec Pharm 23(6): 677-683. https://doi.org/10.18553/jmcp.2017.23.6.677

50. Pozniak P D, Darbinyan A, Khalili K (2016) TNF-a/TNFR2 Regulatory Axis Stimulates EphB2-Mediated Neuroregeneration Via Activation of NF-kB. J Cell Physiol 231(6): 1237-1248. https://doi.org/10.1002/jcp.25219

51. Roskoski R Jr (2017) ROS1 protein-tyrosine kinase inhibitors in the treatment of ROS1 fusion proteindriven non-small cell lung cancers. Pharmacol Res 121: 202-212.

https://doi.org/10.1016/j.phrs.2017.04.022

52. Sethi G, Shanmugam M K, Warrier S, Merarchi M, Arfuso F, Kumar A P, Bishayee A (2018) Pro-Apoptotic and Anti-Cancer Properties of Diosgenin: A Comprehensive and Critical Review. Nutrients 10(5): 645. https://doi.org/10.3390/nu10050645

53. Shen C Y, Jiang J G, Yang L, Wang D W, Zhu W (2017) Anti-ageing active ingredients from herbs and nutraceuticals used in traditional Chinese medicine: pharmacological mechanisms and implications for drug discovery. Br J Pharmacol 174(11): 1395-1425. https://doi.org/10.1111/bph.13631 
54. Shima Y, Teruya K, Ohta H (2016) Association between intronic SNP in urate-anion exchanger gene, SLC22A12, and serum uric acid levels in Japanese. Life Sci 79(23): 2234-2237. https://doi.org/10.1016/j.Ifs.2006.07.030

55. Singh D, Cho W C, Upadhyay G (2016) Drug-Induced Liver Toxicity and Prevention by Herbal Antioxidants: An Overview. Front Physiol 6: 363. https://doi.org/10.3389/fphys.2015.00363

56. Smith E, Hoy D, Cross M, Merriman T R, Vos T, Buchbinder R, Woolf A, March L (2014) The global burden of gout: estimates from the Global Burden of Disease 2010 study. Ann Rheum Dis 73(8): 1470-1476. https://doi.org/10.1136/annrheumdis-2013-204647

57. Tomioka N H, Tamura Y, Takada T, Shibat S, Suzuki H, Uchida S, Hosoyamada M (2016) Immunohistochemical and in situ hybridization study of urate transporters GLUT9/URATV1, ABCG2, and URAT1 in the murine brain. Fluids Barriers CNS 13(1): 22. https://doi.org/10.1186/s12987-016-0046-X

58. Tong J B, Zhang X X, Wang X H, Zeng S J, Wang D Y, Zhang Z Q, Hu J, Yang C, Li Z G (2018) Qiyusanlong decoction suppresses lung cancer in mice via Wnt/ $\beta$-catenin pathway. Mol Med Rep 17(4): 5320-5327. https://doi.org/10.3892/mmr.2018.8478

59. Tran H J, Speyer G, Kiefer J, Kim S (2017) Contextualization of drug-mediator relations using evidence networks. BMC Bioinformatics 18(Suppl 7): 252. https://doi.org/10.1186/s12859-017-1642-8

60. Tran T (2017) Editorial: Recent Development of Drug Delivery Systems for Improving Bioavailability and Pharmacokinetics. Curr Drug Metab 18(11): 972.

https://doi.org/10.2174/138920021811180117141059

61. Vázquez-Mellado J, Jiménez-Vaca A L, Cuevas-Covarrubias S, Alvarado-Romano V, Pozo-Molina G, Burgos-Vargas R. (2007). Molecular analysis of the SLC22A12 (URAT1) gene in patients with primary gout. Rheumatology 46(2): 215-219. https://doi.org/10.1093/rheumatology/kel205

62. Vazquez-Mellado J, Peláez-Ballestas I, Burgos-Vargas R, Alvarez-Hernández E, García-Méndez S, Pascual-Ramos V, Rull-Gabayet M (2018) Improvement in OMERACT domains and renal function with regular treatment for gout: a 12-month follow-up cohort study. Clin Rheumatol 37(7): 1885-1894. https://doi.org/10.1007/s10067-018-4065-7

63. Wang D, Zhang J, Jiang W, Cao Z, Zhao F, Cai T, Aschner M, Luo W (2017) The role of NLRP3-CASP1 in inflammasome-mediated neuroinflammation and autophagy dysfunction in manganese-induced, hippocampal-dependent impairment of learning and memory ability. Autophagy 13(5): 914-927. https://doi.org/10.1080/15548627.2017.1293766

64. Wang J, Molday L L, Hii T, Coleman J A, Wen T, Andersen J P, Molday R S (2018) Proteomic Analysis and Functional Characterization of P4-ATPase Phospholipid Flippases from Murine Tissues. Sci Rep 8(1): 10795. https://doi.org/10.1038/s41598-018-29108-z

65. Wang J, Zhu S, Meng N, He Y, Lu R, Yan G R (2019) ncRNA-Encoded Peptides or Proteins and Cancer. Mol Ther 27(10): 1718-1725. https://doi.org/10.1016/j.ymthe.2019.09.001

66. Wang P, Wu L, Lu Z, Li Q, Yin W, Ding F, Han H (2017) Gecko-Inspired Nanotentacle Surface-Enhanced Raman Spectroscopy Substrate for Sampling and Reliable Detection of Pesticide Residues in Fruits and Vegetables. Anal Chem 89(4): 2424-2431. https://doi.org/10.1021/acs.analchem.6b04324 
67. Wu H, Ding X, Zhao D, Liang Y, Ji W (2019) Effect of montelukast combined with methylprednisolone for the treatment of mycoplasma pneumonia. J Int Med Res 47(6): 2555-2561.

https://doi.org/10.1177/0300060518820412

68. Wu M, Ai W, Chen L, Zhao S, Liu E (2016) Bradykinin receptors and EphB2/EphrinB2 pathway in response to high glucose-induced osteoblast dysfunction and hyperglycemia-induced bone deterioration in mice. Int J Mol Med 37(3): 565-574. https://doi.org/10.3892/ijmm.2016.2457

69. Wu X H, Yu C H, Zhang C F, Anderson S, Zhang Y W (2014) Smilax riparia reduces hyperuricemia in mice as a potential treatment of gout. Am J Chin Med 42(1): 257-259.

https://doi.org/10.1142/S0192415X14200018

70. Xie Z, Wu H, Jing X, Li X, Li Y, Han Y, Gao X, Tang X, Sun J, Fan Y, Wen C (2017) Hypouricemic and arthritis relapse-reducing effects of compound tufuling oral-liquid in intercritical and chronic gout: $\mathrm{A}$ double-blind, placebo-controlled, multicenter randomized trial. Medicine 96(11): e6315. https://doi.org/10.1097/MD.0000000000006315

71. Xie Z, Wu H, Jing X, Li X, Li Y, Han Y, Gao X, Tang X, Sun J, Fan Y, Wen C (2017) Hypouricemic and arthritis relapse-reducing effects of compound tufuling oral-liquid in intercritical and chronic gout: $\mathrm{A}$ double-blind, placebo-controlled, multicenter randomized trial. Medicine 96(11): e6315. https://doi.org/10.1097/MD.0000000000006315

72. Yan Y, Jiang W, Spinetti T, Tardivel A, Castillo R, Bourquin C, Guarda G, Tian Z, Tschopp J, Zhou R (2013) Omega-3 fatty acids prevent inflammation and metabolic disorder through inhibition of NLRP3 inflammasome activation. Immunity 38(6): 1154-1163. https://doi.org/10.1016/j.immuni.2013.05.015

73. Ying Y, Chen Y, Li Z, Huang H, Gong Q (2017) Investigation into the association between P2RX7 gene polymorphisms and susceptibility to primary gout and hyperuricemia in a Chinese Han male population. Rheumatol Int 37(4): 571-578. https://doi.org/10.1007/s00296-017-3669-6

74. Yu S, Wang J, Shen H (2020) Network pharmacology-based analysis of the role of traditional Chinese herbal medicines in the treatment of COVID-19. Ann Palliat Med 9(2): 437-446. https://doi.org/10.21037/apm.2020.03.27

75. Zhang Y, Schauer J J, Zhang Y, Zeng L, Wei Y, Liu Y, Shao M (2017) Environ Sci Technol 51(8): 4734. https://doi.org/10.1021/acs.est.7b01543

\section{Table}

Due to technical limitations, table 1 is only available as a download in the Supplemental Files section.

\section{Figures}




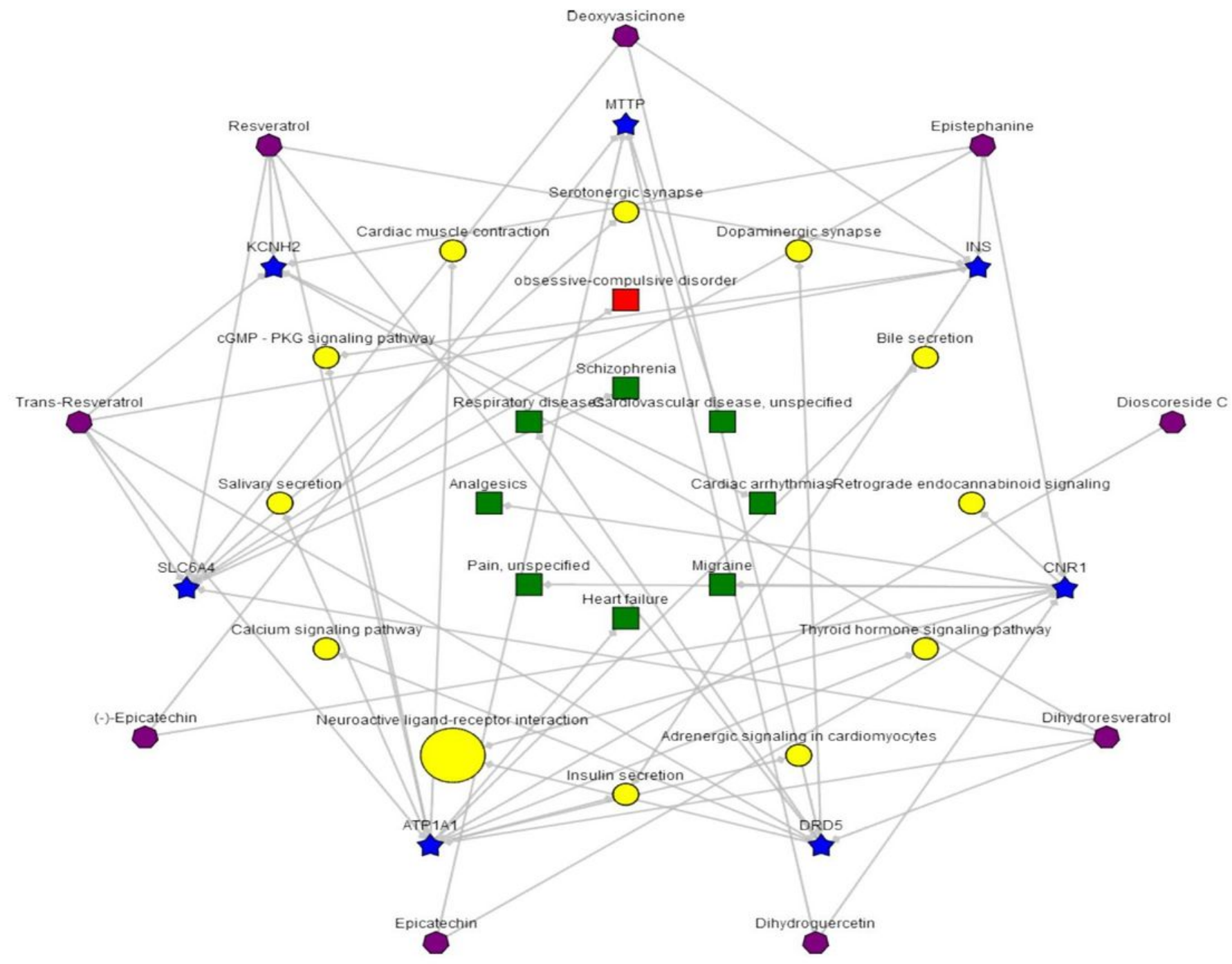

Figure 1

Relationship between modern pharmacology and traditional efficacies of DS (The red and green squares represent the diseases; the yellow circle represents the pathways; the purple heptagon represents the components; and the blue five-pointed star represents the drug targets). 


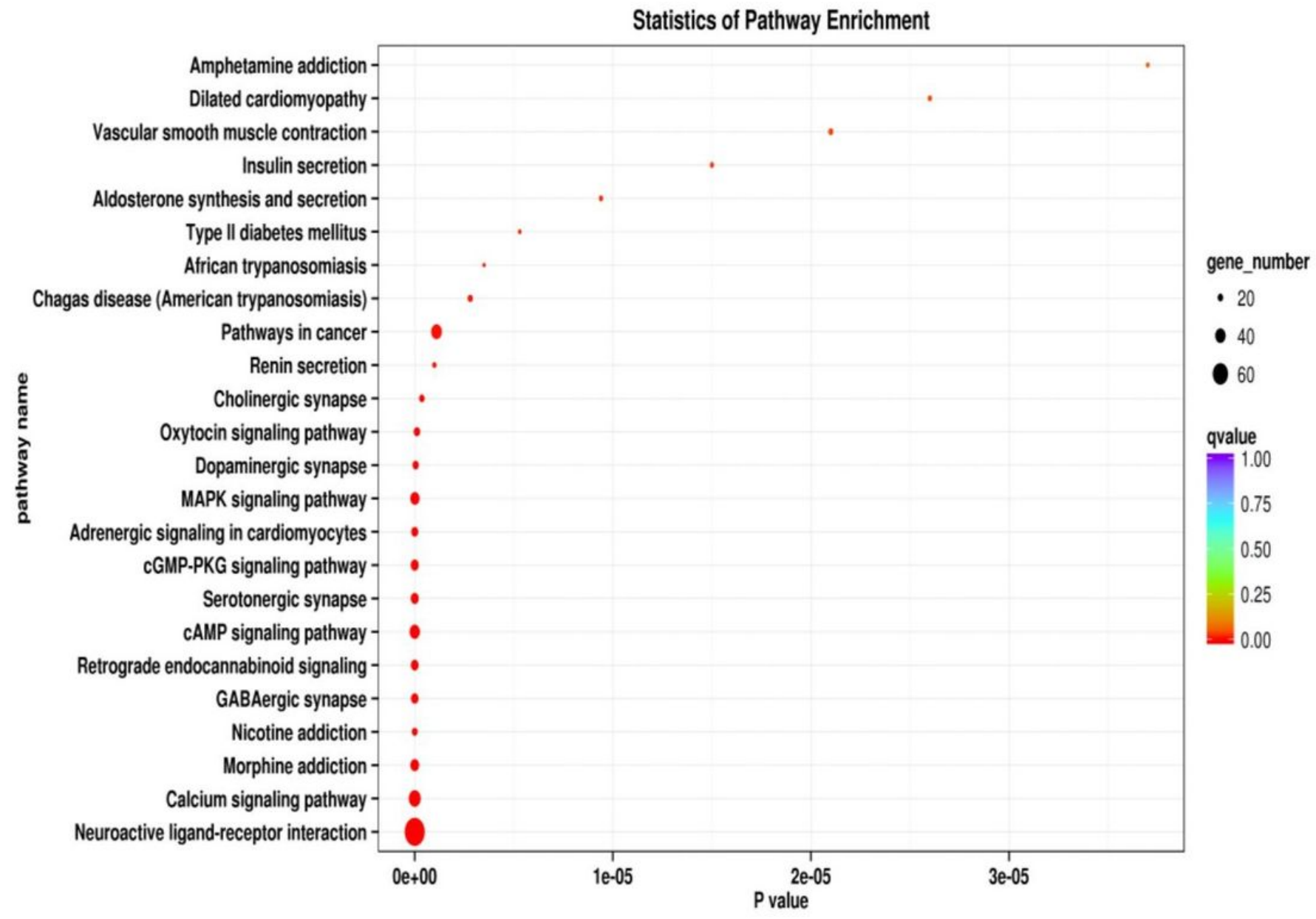

Figure 2

KEGG mechanism analysis 


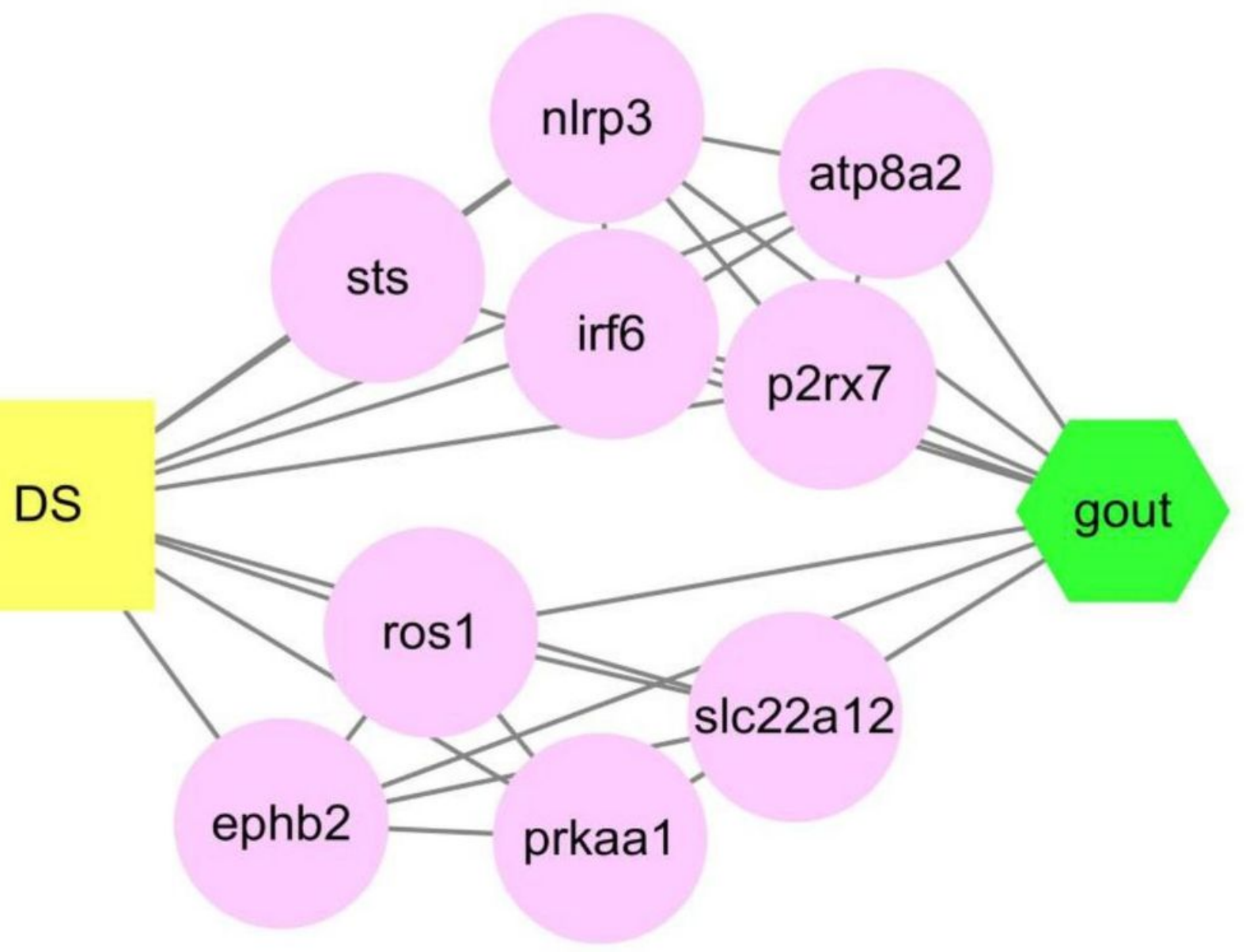

Figure 3

DS shares 9 targets with gout

\section{Supplementary Files}

This is a list of supplementary files associated with this preprint. Click to download.

- Table1ActiveingredientsofDHandSG.docx

- DHcomponds.xls

- SGcomponds.xls

- renamed767c2.xls 